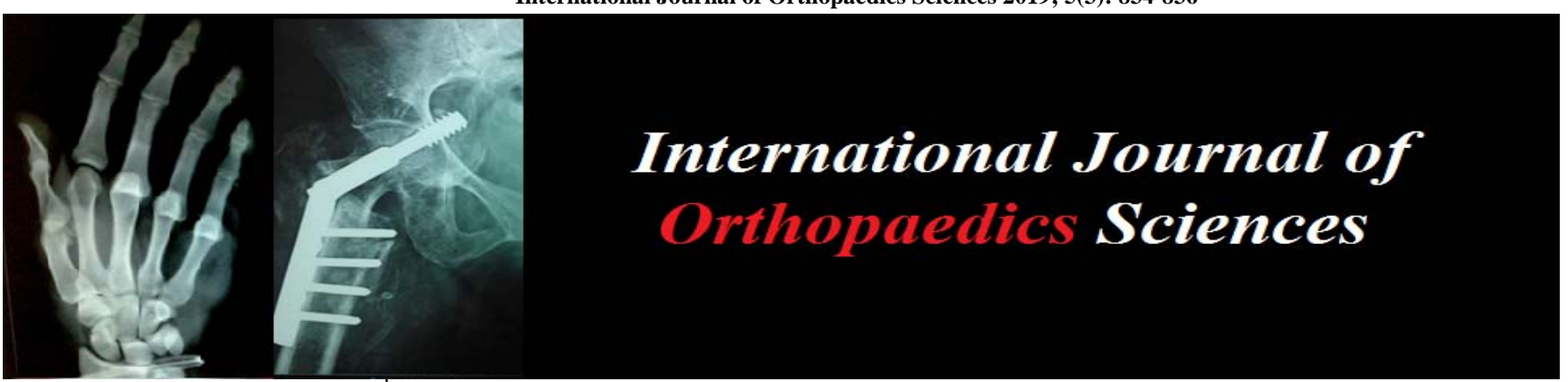

E-ISSN: 2395-1958

P-ISSN: 2706-6630

IJOS 2019; 5(3): 834-836

(C) 2019 IJOS

www.orthopaper.com

Received: 25-05-2019

Accepted: 27-06-2019

Dr. Vavilapalli Ramesh

Associate Professor of Orthopaedics Great Eastern Medical School \& Hospital,

Ragolu, Srikakulam,

Andhra Pradesh, India

Dr. Aneepu Siva Prasad

Assistant Professor of

Orthopaedics, Great Eastern

Medical School \& Hospital,

Ragolu, Srikakulam,

Andhra Pradesh, India

Dr. Baruva Komala Rao Associate Professor of Orthopaedics Great Eastern Medical School \& Hospital,

Ragolu, Srikakulam,

Andhra Pradesh, India

Dr. Aneepu Siva Prasad Assistant Professor of Orthopaedics, Great Eastern Medical School \& Hospital,

Ragolu, Srikakulam,

Andhra Pradesh, India

Correspondence

Dr. Aneepu Siva Prasad Assistant Professor of Orthopaedics, Great Eastern Medical School \& Hospital, Ragolu, Srikakulam, Andhra Pradesh, India

\section{A cross sectional study on correlation of vitamin D levels with types of proximal femoral fractures in elderly patients}

\author{
Dr. Vavilapalli Ramesh, Dr. Aneepu Siva Prasad, Dr. Baruva Komala Rao \\ and Dr. Aneepu Siva Prasad
}

DOI: https://doi.org/10.22271/ortho.2019.v5.i3n.2132

\section{Abstract}

Proximal femoral fractures are very common in elderly patients. These fractures are thought to be associated with osteoporosis. Vitamin D is a possible risk factor for osteoporosis. So, this study was done to evaluate the association of serum vitamin D level with types of femoral fractures in elderly patients. Methods: The study was done between December 2017 to December 2019, 120 patients with age >60 years (male and female both) with proximal femoral fractures were studied. Serum 25-hydroxy vitamin D, calcium, phosphate, alkaline phosphatase levels, liver function test, renal function test, hemoglobin and complete blood counts of all the patients were assessed.

Results: On assessment of serum vitamin D in proximal femoral fracture in elderly patients, it shows an increase incidence of proximal femoral fractures in patients with low serum vitamin D level. Fracture of neck of femur was most common among all. Type of fracture has no significant statistical relationship with serum vitamin D levels.

Conclusions: Osteoporosis and serum vitamin D level depends on age and sex of the patient. But type of proximal femoral osteoporotic fracture has no association with either grade of osteoporosis or serum vitamin D level.

Keywords: proximal femoral fractures, vitamin D, elderly, fracture neck of femur, Osteoporosis

\section{Introduction}

Hip fractures and related disabilities are important public health issues for elderly people around the world including developing nation like India. Actual numbers of fractures are increasing steadily due to the increasing proportion of the elderly population ${ }^{[1]}$. Despite the resources of modern medicine, there is a high mortality rate, around $25-30 \%$ yearly ${ }^{[2,3]}$. However, since the density of population is higher in Asia, by 2050, the incidence of hip fractures is estimated to contribute more than $50 \%$ in the world ${ }^{[4]}$.

Among the micronutrients relating to the risk of falls and fractures among elderly people, vitamin D can be highlighted. Low vitamin D levels are commonly associated with because of multiple factors such as decreased sun exposure with reduced skin production of vitamin D and low dietary D2/D3 intake. The skin's ability to produce vitamin D3 from the pre-vitamin 7-dehydrocholesterol also declines with advancing age ${ }^{[5]}$.

It has been presumed that Indians are vitamin D sufficient as Indian subcontinent is situated between $8.4 \mathrm{~N}$ and $37.6 \mathrm{~N}$ latitude and has adequate sunshine and UV-B rays (290-315 nm) reaching the earth's surface throughout the year. However a recent study has suggested a high prevalence of subnormal 25-hydroxy vitamin D concentration among healthy Indians ${ }^{[6]}$.

In the present study, it was planned to assess serum vitamin D levels and routine bone biochemistry in elderly patients who presented with proximal femoral fractures and to study association of serum vitamin D with osteoporotic proximal femoral fractures in elderly patients and also to study association of type of proximal femoral fracture with grade of osteoporosis and serum vitamin D level. 


\section{Methods}

This cross-sectional study was conducted in the Department of Orthopaedic Surgery, Great Eastern Medical School and Hospital, Srikakulam, during the period between December 2017 and December 2019, after getting approval from research \& ethical committee for the study.

Patients were selected having inclusion criteria age $>60$ years, type of fracture - proximal femoral fractures (neck of femur, intertrochanteric, subtrochanteric fracture), patient having pathological fracture were excluded from study.

Pelvis with both hip -AP view were taken to evaluate diagnosis and classification of fracture. Routine blood investigations including serum vitamin D level, serum calcium level, serum phosphate level, serum alkaline phosphatase level, liver function test, renal function test, were carried out. Serum vitamin D level was tested with 25hydroxy vitamin D ELISA /chemiluminiscence Macropartite Enzyme Immunoassay method.

Chi square test was used for analysis data and get the $\mathrm{p}$ value to know the significance.

\section{Results}

In our study proximal femoral fractures were more common in males and among the males, fracture neck of femur was more common than other proximal femoral fractures. Fracture neck of femur (both male and female) was more common among proximal femoral fractures.

Table 1: Relationship between sex and types of fractures.

\begin{tabular}{|c|c|c|c|c|}
\hline Sex & Fracture Neck of Femur (\%) & Intertrochanteric fracture (\%) & Subtrochanteric fracture (\%) & Total (\%) \\
\hline Male & $42(65.6)$ & $21(32.8)$ & $1(1.5)$ & $64(53.3)$ \\
\hline Female & $36(64.3)$ & $20(35.7)$ & 0 & $56(46.6)$ \\
\hline Total & $78(65)$ & $41(34.2)$ & $1(0.8)$ & $120(100)$ \\
\hline
\end{tabular}

84 patients out of 120 patients were having serum vitamin D Level<20 ng/ml. Type of fracture has no statistical relationship with serum vitamin D levels.

Table 2: Relationship between age and vitamin D3 level.

\begin{tabular}{|c|c|c|c|}
\hline \multirow{2}{*}{ Age (in years) } & \multicolumn{2}{|c|}{ Serum Vitamin D Levels (ng/mL) } & \multirow{2}{*}{ Total } \\
\cline { 2 - 3 } & $<\mathbf{2 0}$ & $\mathbf{2 0}-\mathbf{1 0 0}$ & 87 \\
\hline $60-70$ & 59 & 28 & 23 \\
\hline $71-80$ & 17 & 6 & 10 \\
\hline$>80$ & 8 & 2 & $120(100 \%)$ \\
\hline Total & $84(70 \%)$ & $36(30 \%)$ & \\
\hline
\end{tabular}

Table 3: Relationship between serum vitamin D3 level and type of fractures.

\begin{tabular}{|c|c|c|c|c|}
\hline $\begin{array}{c}\text { Serum Vitamin D3 Level } \\
\text { (ng/mL) }\end{array}$ & $\begin{array}{c}\text { Fracture Neck of } \\
\text { Femur (\%) }\end{array}$ & $\begin{array}{c}\text { Intertrochanteric fracture } \\
\mathbf{( \% )}\end{array}$ & $\begin{array}{c}\text { Subtrochanteric } \\
\text { fracture (\%) }\end{array}$ & Total (\%) \\
\hline$<20$ & $52(68.4)$ & $24(31.6)$ & 0 & $76(63.3)$ \\
\hline $20-100$ & $26(59.1)$ & $17(38.6)$ & $1(2.2)$ & $44(36.6)$ \\
\hline Total & $78(65)$ & $41(34.2)$ & $1(0.8)$ & $120(100)$ \\
\hline
\end{tabular}

Proximal femoral fractures are slightly more common in patients having serum vitamin $\mathrm{d} 3$ level $<20 \mathrm{ng} / \mathrm{ml}$ as compared to patients having serum vitamin d3 level $>20 \mathrm{ng} / \mathrm{ml}$. Distribution of type of fracture is almost same in both the groups. Type of fracture has no significant relationship with serum Vitamin d3 levels.

\section{Discussion}

The role of vitamin D in maintaining musculoskeletal health is already evident. It does so by its role in regulation of calcium absorption, mineralization of bone and its effect on muscle function physiology ${ }^{[7,8]}$.

In our study, we studied 120 patients of proximal femoral fractures which include fracture neck of femur, intertrochanteric fractures and subtrochanteric fractures. 65\% had fracture neck of femur, $34.2 \%$ had fracture intertrochanteric and $0.8 \%$ had fracture subtrochanteric.

Out of those patients $53.3 \%$ patients were male and $46.6 \%$ were female, which comes to 1.14:1 of male to female ratio, study conducted by Ramalho, Lazaretti-Castro, found male female ratio for elderly patients with proximal femoral fractures to be 1:3.1 and by Bartonícek, Dzupa, Fric, 1:2.5 [9, 10].

In our study $70 \%$ of patients have serum vitamin D level $<20$ $\mathrm{ng} / \mathrm{ml}$ and 30\%have serum vitamin D level 20-100 ng/ml. In study done by Kristine, Ensrud, Brent, Taylor, Misti, Paudel, they found serum vitamin D level of 110 men (9\%) had a 25 (OH) D level below $15.0 \mathrm{ng} / \mathrm{ml}, 184(14 \%)$ had a $25(\mathrm{OH}) \mathrm{D}$ level of 15.0-19.9 ng/ml, $605(47 \%)$ had a $25(\mathrm{OH}) \mathrm{D}$ level of 20.0-29.9 ng/ml, and 376 (29\%) had a $25(\mathrm{OH})$ D level of at least $30.0 \mathrm{ng} / \mathrm{ml}$. Our results are very similar to those recently reported from an Italian study of Isaia et al. ${ }^{[11,12]}$

Harinarayan et al found $18 \%$ of patients serum vitamin D level $>20 \mathrm{ng} / \mathrm{ml}, 52 \%$ patients have serum vitamin D level 10$20 \mathrm{ng} / \mathrm{ml}$, and $30 \%$ patients have serum vitamin D level $<10$ $\mathrm{ng} / \mathrm{ml}^{[13]}$.

We did not find any difference in the $25(\mathrm{OH})$ D levels between patients with femoral neck and trochanteric fractures, in agreement with a previously published study ${ }^{[14]}$. In contrast, a study done in Crete found that patients with trochanteric fractures had lower levels of $25(\mathrm{OH}) \mathrm{D} .15$

\section{References}

1. Kanis JA, Odén A, McCloskey EV, Johansson H, Wahl DA, Cooper C. IOF Working Group on Epidemiology and Quality of Life. A systematic review of hip fracture incidence and probability of fracture worldwide. Osteoporos Int. 2012; 23(9):2239-56.

2. Fernandes RA, Araújo DV, Takemoto MLS, Sauberman MV. Fraturas do fêmur proximal no idoso: estudo de 
custo da doença sob a perspectiva de um hospital público no Rio de Janeiro, Brasil. Physis. 2011; 21(2):395-416.

3. Ricci G, Longaray MP, Gonçalves RZ, Ungaretti Neto AS, Manente M, Barbosa LBH. Avaliação da taxa de mortalidade em um ano após fratura do quadril e fatores relacionados à diminuição da sobrevida no idoso. Rev Bras Ortop. 2012; 47(3):304-9.

4. Cooper C, Campion G, Melton LJ., 3rd Hip fractures in the elderly: A world-wide projection. Osteoporos Int. 1992; 2:285-9.

5. MacLaughlin J, Holick MF (1985) Aging decreases the capacity of human skin to produce vitamin D3. J Clin Invest. 1985; 76:1536-8.

6. Goswami R, Gupta N, Gosami D, Marwaha RK, Tandon N, Kochupillai N. Prevalence and significance of low 25hydroxyvitamin $\mathrm{D}$ concentration in healthy subjects in Delhi. AMJ Clin Nutr. 2000; 72(2):472-5.

7. Holick MF. McCollum award lecture 1994. Vitamin D: new horizons for the 21st century. Am J Clin Nutr. 1994; 60:619-30.

8. Holick MF. Environmental factors that influence the cutaneous production of vitamin D. Am J Clin Nutr. 1995; 61(Suppl 3):638S-645S.

9. Ramalho AC, Lazaretti-Castro1 $\mathrm{M}$, Hauache $\mathrm{O}$, Kasamatsu T, Brandão C, Reis AF, et al. Brazilian Fractures of the proximal femur- correlation with Vitamin D Receptor gene polymorphism. J Med Biological Res. 1998; 31(7):921-7.

10. Bartonícek J, Dzupa V, Fric V, Pacovský V, SkálaRosenbaum J, Svatos F. Epidemiology and economic implication of fractures of proximal femur, proximal humerus, distal radius and fracture dislocation of ankle. 2008; 87(4):213-9.

11. Ensrud KE, Taylor BC, Paudel ML, Cauley JA, Cawthon PM, Cummings SR, et al. Serum 25-hydroxyvitamin D levels and rate of hip bone losing older men. J Clin Endocrinol Metab. 2009; 94(8):2773-80.

12. Isaia G, Giorgino R, Rini GB, Bevilacqua M, Maugeri D, Adami S. Prevalence of hypovitaminosis D in elderly women in Italy: clinical consequences and risk factors. Osteoporos Int. 2003; 14:577-82.

13. Harinarayan CV, Joshi SR. Vitamin D status in india-It's implications and remedial measures. J Assoc Physicians India. 2009; 57:40-8.

14. Bruce DG, St John A, Nicklason F, Goldswain PR. Secondary hyperparathyroidism in patients from Western Australia with hip fracture: Relationship to type of hip fracture, renal function and vitamin D deficiency. J Am Geriatr Soc. 1999; 47:354-9.

15. Fisher A, Srikusalanukul W, Davis M, Smith P. Hip fracture type: Important role of parathyroid hormone $(\mathrm{PTH})$ response to hypovitaminosis D. Bone. 2010; 47(2):400-7 